\title{
Processing of Copper Based Foil Hardened with Zirconia by Non-Deformation Method
}

\author{
Luiz Eloi Vieira Junior ${ }^{a, b *}$, Tatiana Bendo ${ }^{a}$, Maria Izabel Nieto ${ }^{c}$, Aloísio Nelmo Klein ${ }^{a}$, \\ Dachamir Hotza ${ }^{a}$, Rodrigo Moreno ${ }^{c}$, João Batista Rodrigues Neto ${ }^{a}$
}

\author{
${ }^{a}$ Programa de Pós-graduação em Ciência e Engenharia de Materiais - PGMAT, Universidade Federal \\ de Santa Catarina - UFSC, 88040-970, Florianópolis, SC, Brazil \\ ${ }^{b}$ Fundação Universidade Regional de Blumenau, 89030-000, Blumenau, SC, Brazil \\ ${ }^{c}$ Instituto de Cerámica y Vidrio - ICV, Consejo Superior de Investigaciones Científicas - \\ CSIC, 28049, Madrid, Spain
}

Received: August 2, 2016; Revised: March 6, 2017; Accepted: April 5, 2017

\begin{abstract}
Flat sintered copper and copper-zirconia substrates, with zirconia nanoparticles contents of 1 and $3 \mathrm{vol} \%$, were produced by aqueous tape casting and controlled sintering. Aqueous suspensions were prepared to a solid content of $58 \mathrm{vol} \%$ using $3 \mathrm{wt} \%$ commercial binder emulsion. The green tapes were treated at $350{ }^{\circ} \mathrm{C}$ in air to remove organics and sintered at temperatures ranging from 800 to $1000{ }^{\circ} \mathrm{C}$ in atmosphere of $\mathrm{Ar} / 5 \% \mathrm{H}_{2}$. Copper tapes reached almost full densification at $900{ }^{\circ} \mathrm{C}$. Composite with $1 \mathrm{vol} \%$ zirconia, sintered at $800{ }^{\circ} \mathrm{C}$, maintained high density and provided a noticeable increase of the mechanical strength, whereas further additions up to $3 \mathrm{vol} \%$ reduced the densification and the resulting mechanical performance became poorer.
\end{abstract}

Keywords: Tape casting, Copper-zirconia, Metal-matrix composites, Particle-reinforcement, Mechanical testing

\section{Background}

Copper is one of the most important non-ferrous metals used at large scale in industry. Its main property is the electrical conductivity, which is just below that of silver. Copper is generally used as bronze alloys with additions of $\mathrm{Ni}, \mathrm{Sn}, \mathrm{Pb}$ and $\mathrm{C}$ (graphite bronze). Copper alloys are used in environments requiring high corrosion resistance, ductility and thermal and electrical conductivities ${ }^{1}$. According to the literature, the values obtained from mechanical strength for copper commercially vary considerably depending on the manufacturing techniques products, such as molten copper and thermally treated or forged with severe deformations that require time and energy to achieve the final mechanical properties and which are correlated with the final grain size. In case of sintered components required properties is related mainly its porosity, in this case, an inversely proportional relationship. These values include tens $(<50 \mathrm{MPa})$ to a few hundred $(<400 \mathrm{MPa})^{2-4}$.

Another useful tool for increasing the mechanical strength and wear of copper components can be the introduction of ceramic particles which are homogeneously dispersed. Table 1 shows some examples of ceramic materials used as reinforcement in copper matrix. As can be seen, there are a variety of ways to increase the mechanical strength of copper. Note that adding micrometer particles can increase their concentration within the metal matrix. Moreover, by adding up submicron or nanoscale particles, the concentrations are

*e-mail: eloi_junior@hotmail.com reduced because of the greater amount of ceramic composite particles per volume, leading to the reduction of their required mechanical and electrical properties.

Conventional routes for the production of metal alloys and composite sintered with dispersion of nanoscale particles, such as high energy milling require high processing times for mixing, milling and dispersion of the second phase, and the thermal annealing treatment ${ }^{17,18}$. The colloidal route provides an alternative way to produce nanostructured composites with excellent microstructural homogeneity. Using knowledge dispersion of particles consolidated in the production of ceramic materials, the mixing process and homogenization phase in liquid medium is far more efficient than dry. Finally is obtained a different microstructure, controlled and reproducible beyond much less processing time than conventional processes.

Among those applications, the potential use as a component in solid oxide fuel cells (SOFCs) is receiving current attention. There is an increasing interest to reduce the operating temperatures of SOFCs below $800^{\circ} \mathrm{C}$ without a remarkable loss in efficiency. The configuration using $\mathrm{Ni}$ / YSZ as the anode, however, presents some disadvantages. When hydrocarbons are used as fuel, carbon deposition in the form of whiskers can occur decreasing the operational performance $^{19}$. To solve this problem, copper anodes have been tested. Copper does not present the inconvenience of carbon deposition, it is reasonably tolerant to the presence of sulfur and is cheaper than nickel. Copper-based composites 
Table 1. Examples of ceramic materials used to produce copper matrix composites.

\begin{tabular}{|c|c|c|c|c|c|}
\hline Reinforcement & Size $(\mu \mathrm{m})$ & Vol.\% & Processing & $\begin{array}{l}\text { Mechanical strength } \\
(\mathrm{MPa})\end{array}$ & Ref. \\
\hline $\mathrm{Ti}_{3} \mathrm{AlC}_{2}$ & 45 & $2.3-9.4$ & HP & $280-600$ & {$[5]$} \\
\hline C-nanotube & 0,02 & $0-2.0$ & $\mathrm{CP}$ & $\mathrm{x}$ & [6] \\
\hline Ni coated $\mathrm{C}$ & $0.2-0.3$ & 1.9 & $\mathrm{HP}$ & $\mathrm{x}$ & [7] \\
\hline $\mathrm{SiC}$ & 75 & $5.0-20$ & $\mathrm{HP}$ & $150-97$ & {$[8]$} \\
\hline $\mathrm{TiB}_{2}$ & $3.0-5.0$ & $15-60$ & $\mathrm{HP}$ & $150-650$ & [9] \\
\hline $\mathrm{Zr}_{2} \mathrm{Al}_{3} \mathrm{C}_{4}$ & 25 & $5.0-25$ & $\mathrm{CP}$ & $180-350$ & {$[10]$} \\
\hline Diamond & $40-50$ & $0-14$ & HP & $\mathrm{x}$ & {$[11]$} \\
\hline C-nanotube & $0.01-0.02$ & $0.1-0.4$ & HP & $100-300$ & [12] \\
\hline $\mathrm{Al}_{2} \mathrm{O}_{3}$ & $<0.1$ & $1.3-3.8$ & $\mathrm{CP}$ & $<40$ & [13] \\
\hline C-Fiber & $>0.2$ & 33 & HP & $150-270$ & [14] \\
\hline $\mathrm{TiB}_{2}$ & - & 0.77 & Infiltration & $300-510$ & {$[15]$} \\
\hline $\mathrm{Ti}_{2} \mathrm{SnC}$ & 0.5 & $5.0-30$ & $\mathrm{CP}$ & $164-326$ & [16] \\
\hline
\end{tabular}

Legend: HP: Hot pressing; CP: Cold pressing.

like $\mathrm{Cu} / \mathrm{YSZ}$ and $\mathrm{Cu} / \mathrm{CeO}_{2}$ have been proposed as anodes to work at intermediate temperatures ${ }^{20,21}$.

However, a major limitation for those applications is to find suitable processing routes capable to produce homogeneous mixtures of metal powders with small amounts of ceramic particles. The scenario is much more complicated when one of the phases lies within the nanometric range. To obtain such nanostructured composites, the use of colloidal processing routes has demonstrated to be a powerful route. One of the most popular colloidal methods for shaping ceramics is tape casting, which is a low-cost technique for the production of thin substrates through a deposition/ evaporation mechanism. Tape casting is widely used to produce capacitors, sensors, piezoelectrics, heat sinks, and electrodes for $\mathrm{SOFC}^{22-24}$. As in any colloidal processing route, a major concern is the preparation of a well-dispersed suspension with the highest solids content, thus requiring the suitable selection of a deflocculant ${ }^{25-30}$ Other processing additives such as binders and plasticizers are also needed to provide the desired strength and flexibility. In order to produce suitable substrates, the slurries should behave as pseudoplastic fluids to have adequate flowability during casting and high viscosity at rest.

This research aims to produce thick films of $\mathrm{Cu}-\mathrm{ZrO}_{2}$ composites by an aqueous tape casting route for obtaining homogeneous mixtures of metallic copper with zirconia nanoparticles. Tape casting performance will be optimized on the basis of the rheological behavior of differently prepared suspensions and the selection of the most appropriate thermal treatments for debinding in air atmosphere, and sintering under $\mathrm{Ar} / 5 \% \mathrm{H}_{2}$.

\section{Methods}

A commercial copper powder (602 ACu Powder, USA) with a mean particle size of $4.5 \mu \mathrm{m}$, a surface area of $0.3 \mathrm{~m}^{2} \cdot \mathrm{g}^{-1}$ and a density of $8.7 \mathrm{~g} \cdot \mathrm{cm}^{-3}$, and a commercial aqueous zirconia colloidal suspension (MELox nanosize undoped, Mel Chemicals, UK) with average particle size of $50 \mathrm{~nm}$, a surface area of $90 \mathrm{~m}^{2} \cdot \mathrm{g}^{-1}$ and a density of $5.2 \mathrm{~g} \cdot \mathrm{cm}^{-3}$ were used as starting materials.

According to previous studies ${ }^{31}$, concentrated aqueous suspensions of $\mathrm{Cu}$ powders were prepared with a polyelectrolyte at basic $\mathrm{pH}$ in order to prevent dissolution and to promote the development of $\mathrm{Cu}(\mathrm{OH})_{2}$ enriched species at the surface. An acrylic-based polyelectrolyte (Duramax D-3005, Rohm \& Haas, USA, with an average molecular weight of $\sim 2,400$ ) was used as a dispersant in a concentration of $0.15 \mathrm{wt} \%$ on a dry solids basis. The $\mathrm{pH}$ was adjusted to 10 by adding tetramethylammonium hydroxide (TMAH). Suspensions of $\mathrm{Cu}-\mathrm{ZrO}_{2}$ mixtures were prepared with zirconia contents of $1 \mathrm{vol} \%(\mathrm{Cu}-1 \mathrm{Z})$ and $3 \mathrm{vol} \%(\mathrm{Cu}-3 \mathrm{Z})$ in deionized water to solids loadings of $58 \mathrm{vol} \%$ using an ultrasound probe (Sonotrode UP 400S, IKA, Germany) for 2 min. Tape casting suspensions were prepared by adding a polyacrylic-based binder (Duramax B-1000, Rohm \& Haas, USA) to the dispersed slurries. This binder is a latex emulsion with a $\mathrm{T}_{\mathrm{g}}$ of $-26^{\circ} \mathrm{C}$ and $55 \mathrm{wt} \%$ active matter. Concentrations of 1.0 and 3.0 $\mathrm{wt} \%$ (on a dry solids basis) referred to the as-received binder emulsions (i.e. 0.55 and $1.65 \mathrm{wt} \%$ active matter, respectively) were added. Rheological characterization was carried out using a rheometer (RS50, Thermo Haake, Germany) with a double-cone/plate sensor configuration (DC60/2 $2^{\circ}$, Thermo Haake, Germany) and a testing temperature of $25.0 \pm 0.5^{\circ} \mathrm{C}$. The flow behavior was measured under CR (controlled shear rate) mode. To obtain the high shear flow behavior, CR experiments were carried out employing a measuring program in three stages: first a linear increase of shear rate from 0 to $1000 \mathrm{~s}^{-1}$ in $3 \mathrm{~min}$; a plateau at the maximum shear rate for $1 \mathrm{~min}$, and a decrease to zero shear rate in $3 \mathrm{~min}$.

To produce the green tapes, a self-made tape casting machine was used, which consists of a mobile container with 
the blade and a fixed carrier. A Mylar substrate was used as carrier film. The casting parameters were $50 \mathrm{~mm} \cdot \mathrm{s}^{-1}$ of casting speed and $200 \mu \mathrm{m}$ of gap height between the blade and the carrier film. The green tapes were characterized in terms of density and thickness and were cut into discs with $15 \mathrm{~mm}$ in diameter in order to study the best treatments for burning out the binders and densification. The thermal tests were done using differential thermal analysis (DTA) and thermogravimetry (TG) with a STA 409 equipment (Netzsch, Germany).The analysis was performed in air until $800^{\circ} \mathrm{C}$ in order to establish the debinding conditions.

The sintering studies of the copper and $\mathrm{Cu}-\mathrm{ZrO}_{2}$ composites samples were produced by slip casting. Samples were cast within a metal mould of $20 \mathrm{~mm}$ diameter on a plaster plate and demoulded after 24 hours. Therefore, the green cast compacts were grinded to achieve a rectangular geometry and heat treated at $500{ }^{\circ} \mathrm{C}$ for 40 minutes to eliminate the dispersant. The dynamic sintering behaviour of the specimens was studied with a differential dilatometer (Netzsch $402 \mathrm{EP}$, Germany) up to $900^{\circ} \mathrm{C} / 1 \mathrm{~h}$ under reducing conditions $\left(\mathrm{Ar} / 5 \mathrm{H}_{2}\right.$ flowing atmosphere). The green and sintered densities of the tapes were measured using the Archimedes' method. The tensile strength of the green and sintered tapes was determined using a dynamic mechanical analyzer (TA-XTPlus, Stable MicroSystems, Surrey, UK) equipped with mechanical edge grips and a $500 \mathrm{~N}$ load cell, with a cross-head speed of 0.5 $\mathrm{mm} \cdot \mathrm{min}^{-1}$. Tensile test specimens were cut to rectangular bars of $40 \mathrm{~mm}$ height and $25 \mathrm{~mm}$ width and variable thickness according to the concentration of zirconia nanoparticles. Microstructural characterization of green and sintered tapes was carried out by scanning electron microscopy (Jeol JSM-6701F, Japan).

\section{Results and Discussions}

Figure 1a shows the flow curves of $\mathrm{Cu}$-based suspensions containing different contents of zirconia nanoparticles.

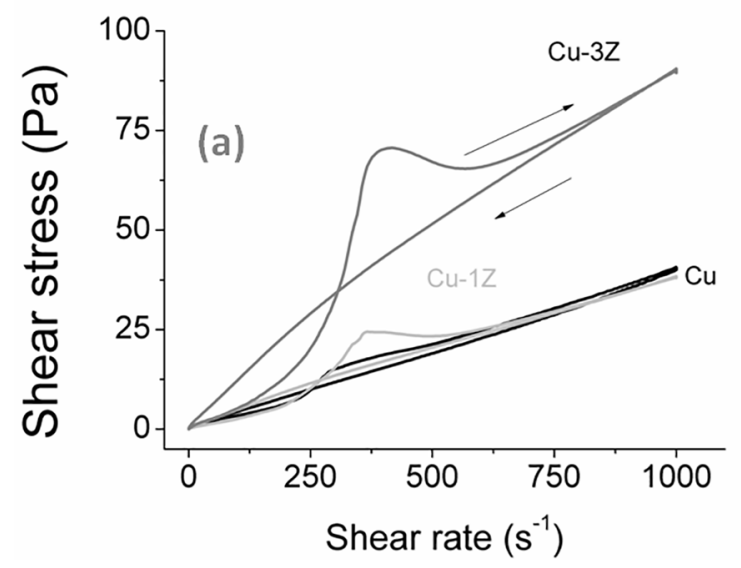

Copper suspensions presented a shear thinning rheological behavior with very slight thixotropy. However, the suspensions containing a small fraction of zirconia show a complex behavior consisting of a shear thickening behavior until a high shear rate value in which the flow becomes nearly Newtonian. The down curve shows a slightly shear thinning behavior. The complex thickening behavior observed in the up curve of the measurement occurs at shear rates between 300-600 s $\mathrm{s}^{-1}$ and is typical of polymers that can extend the chains as a consequence of the shear forces operating as shear rate increases until they reach a maximum stretching and the chains break down. At this point the thickening behavior changes to a thinning or nearly Newtonian one, as expected in the high shear regime. This phenomenon has been previously observed in ceramic suspensions containing gelling polysaccharides ${ }^{32}$, and in the present case may be attributed to the presence of organic additives existing in the zirconia colloidal suspension. The starting suspension has very little content of water in its formulation (less than 10 $\mathrm{wt} \%$ ). The addition of the zirconia nanoparticles to produce the composites significantly affects the rheological behavior. The increase of viscosity with the zirconia content is clearly observed in Figure $1 \mathrm{~b}$ that shows the viscosity values at a shear rate of $100 \mathrm{~s}^{-1}$. This should be related to the large differences between the specific surface areas of both powders, so that a proper evaluation of the nanoparticles concentration is needed to produce the composites. Considering the particles sizes and surface areas, the volume of nanoparticles necessary to achieve a full coating over the copper particles would be $1.14 \%$. This is in good agreement with the flow curve of the $\mathrm{Cu}-1 \mathrm{Z}$ suspension, which is very similar to that of the pure copper aqueous suspension. However, in the case of the $\mathrm{Cu}-3 \mathrm{Z}$ suspension the excess of zirconia nanoparticles remains dispersed in the liquid producing a square root increase of the viscosity.

Figure 2 shows the effect of the polymeric binder on the flow behavior of the studied suspensions. The results are

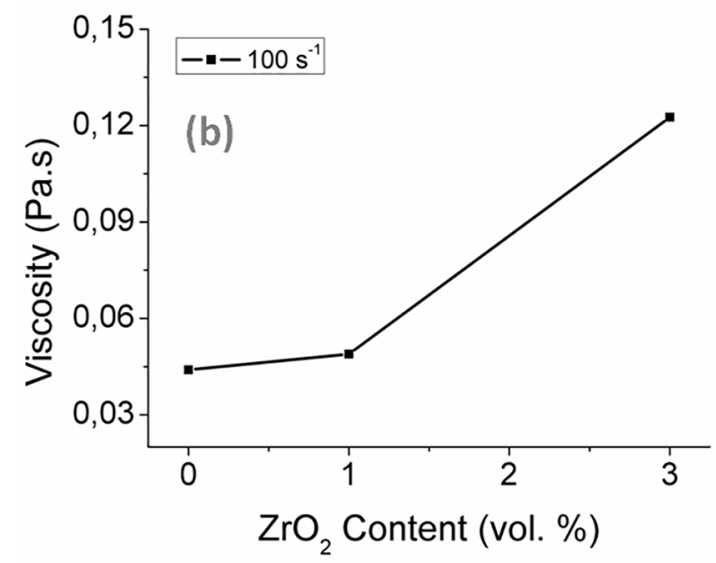

Figure 1. CR flow curves of $\mathrm{Cu}$ and $\mathrm{Cu}-\mathrm{ZrO}_{2}$ aqueous suspensions with a solids content of 58 vol.\% (a) and viscosity at a shear rate of $100 \mathrm{~s}^{-1}$ of the suspensions as a function of zirconia volume content (b). 
very different depending on the binder content. The addition of $1.0 \mathrm{wt} \%$ makes the viscosity to strongly increase and some thixotropy appears. However, the addition of $3.0 \mathrm{wt} \%$ binder has the opposite effect and viscosity decreases with respect to that without binder, establishing this optimized concentration to produce copper and $\mathrm{Cu}-\mathrm{ZrO}_{2}$ tapes. This could be due to the incorporation of additional water with the binder emulsion as observed in previous works ${ }^{33}$. The added amount of water is very low (about $1.5 \mathrm{wt} \%$ additional water), but considering the very high volume fraction of particles in suspension close to the maximum packing fraction a small addition makes the viscosity to significantly decrease. The addition of the binder resulted in the dilution of suspensions for concentrations close to $52 \%$ vol. Then, suspensions were cast using a Mylar film as a carrier surface. Figure 3 shows the aspect of the resulting dry tape of copper. These tapes were easily peeled out from the carrier film, being flexible, homogeneous and presenting no visible cracks or defects.

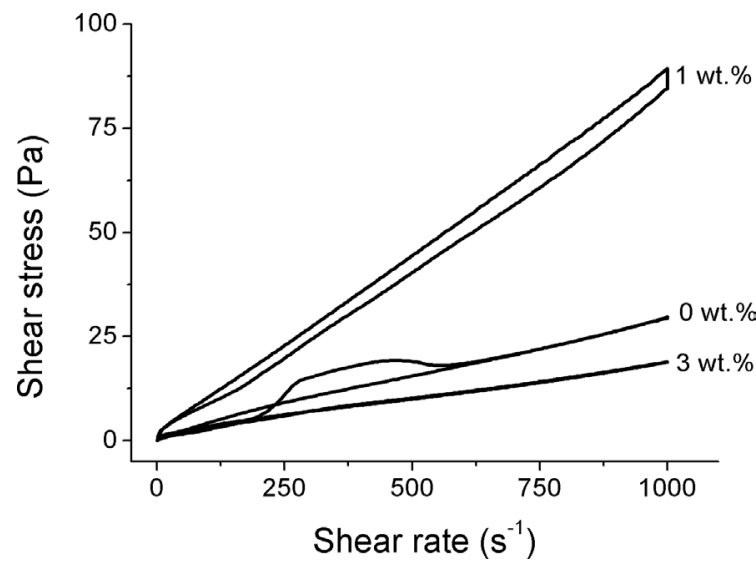

Figure 2. CR flow curves of aqueous copper suspensions to different weight concentrations of binder.

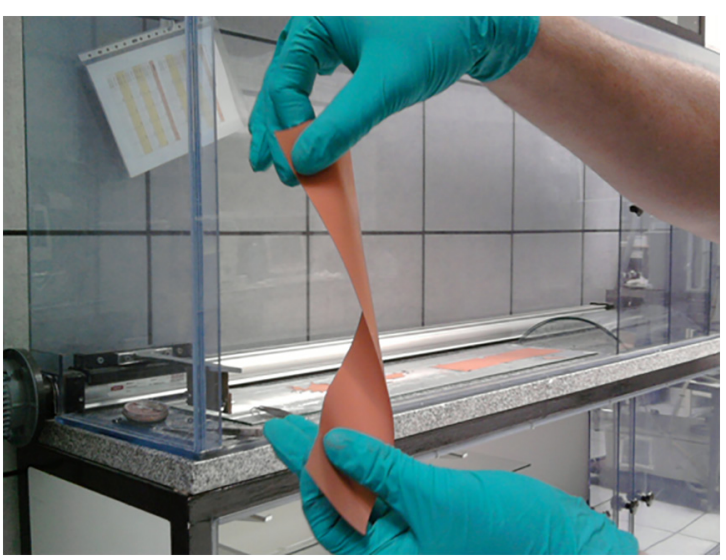

Figure 3. Copper green tape with $3.0 \mathrm{wt} \%$ binder.

In order to select the adequate binder burnout treatment, TG test was performed in air up to $800^{\circ} \mathrm{C}$. Figure 4 shows the TG curve corresponding to a green tape prepared with
$3.0 \mathrm{wt} \%$ binder. The resulting curve was divided into three zones to discussion. In zone I, no representative thermal events are yet observed. Zone II starts at approximately 220 ${ }^{\circ} \mathrm{C}$, indicating the onset temperature of the organic binder burnout. In this zone, the results show the mass loss is about $1.0 \mathrm{wt} . \%$. Considering that the total amount of binder in the sample is $3.0 \mathrm{wt} \%$, the remaining organics are removed later, but it cannot be detected because there is a competitive oxidation process accompanied by a weight increase that masks the weight loss due to organics removal. For higher temperatures in zone III (above $350^{\circ} \mathrm{C}$ ) the oxidation process continues although the oxidation rate is lower than in zone II. This phenomenon can be associated to a restrictive effect of diffusion/percolation of oxygen into the core of the tape. According to these results, a thermal treatment at $350^{\circ} \mathrm{C}$ for $1 \mathrm{~h}$, with heating rate of $1^{\circ} \mathrm{C} / \mathrm{min}$, was selected to perform a complete tape thermal debinding.

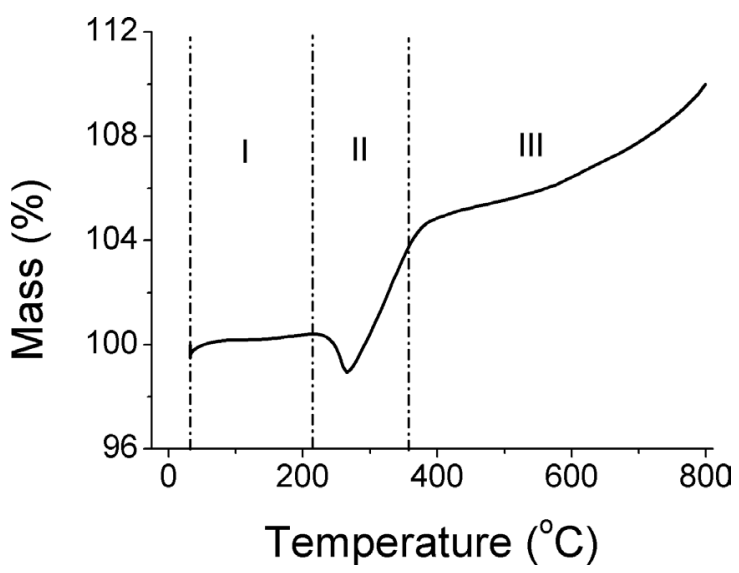

Figure 4. TG result for a copper green tape with $3.0 \%$ of binder in air atmosphere.

The thermal treatment performed for the tapes debinding promotes some oxidation of the outer surface of the tape. Figure 5 shows a general view of the cross-section of the different tapes after debinding as observed by optical microscopy. It can be clearly seen that tapes have an outer oxidation layer whereas the inner region shows the presence of a black core associated to the formation of copper oxides inside the tapes, so that there is an oxygen diffusion region towards the center of the tape. In fact, as can be observed in Figure 5, the black core in the tape with 3 vol\% zirconia is the most representative, since in this case the open porosity is highest. The thickness of this oxidation layer (shown also in Figure 6) increases with increasing zirconia content, as it could be expected.

In order to optimize the sintering conditions, prevent further oxidation and achieve the densification, dynamic sintering studies were performed up to $900^{\circ} \mathrm{C}$ under $\mathrm{Ar} / 5 \% \mathrm{H}_{2}$ flowing atmosphere using $\mathrm{Cu}$ and $\mathrm{Cu}-\mathrm{ZrO}_{2}$ green slip cast samples. Figure 7 shows the dilatometric curves, from 

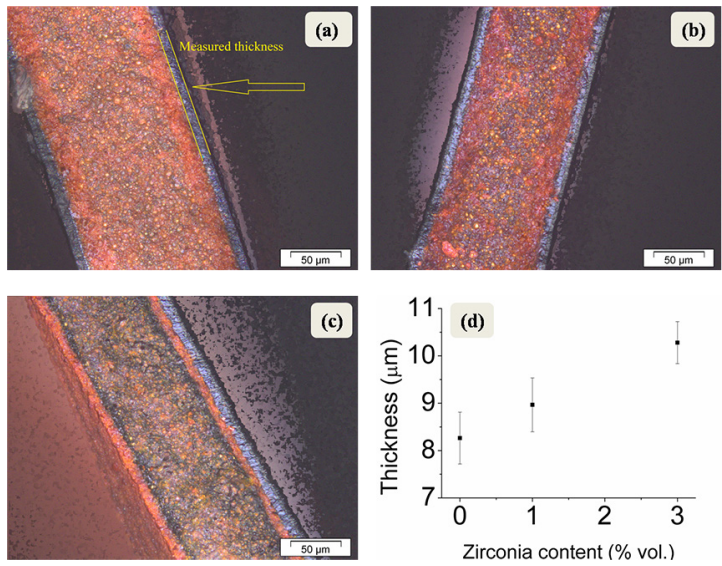

Figure 5. Optical microscopy images showing cross-sections of the different tapes after debinding: (a)Cu; (b)Cu-1Z; (c)Cu-3Z and; (d) thickness of the oxidation layer as function of zirconia content.

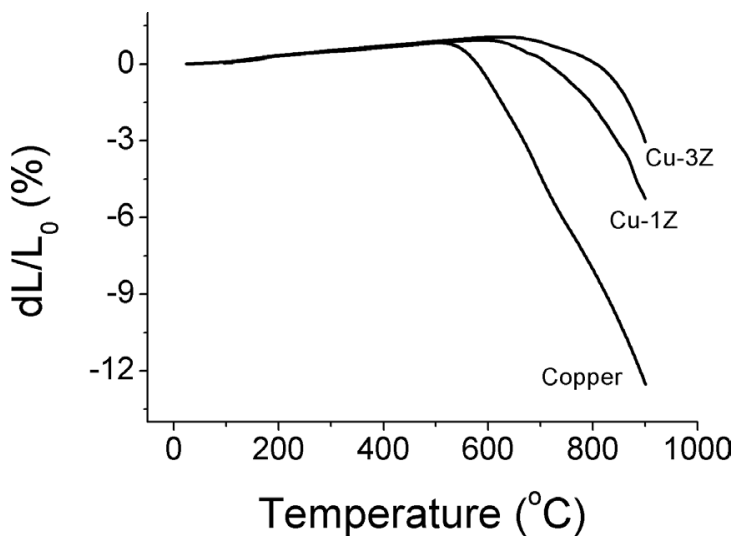

Figure 6. Dynamic sintering curves of $\mathrm{Cu}$ and $\mathrm{Cu}-\mathrm{ZrO}_{2}$ composites at $900{ }^{\circ} \mathrm{C}$ in $\mathrm{Ar} / 5 \% \mathrm{H}_{2}$ atmosphere.

which it can be seen that in the case of $\mathrm{Cu}$ samples the total shrinkage registered was about $12 \%$ and that sintering starts from $500^{\circ} \mathrm{C}$; this is an expected temperature for sintering of copper powders $^{34}$ The highest densification rate is achieved at $690^{\circ} \mathrm{C}$. After this temperature, the densification rate starts a process of reduction, indeed a typical asymptotic curve of the sintering event. From $760^{\circ} \mathrm{C}$ the increased sintering rate can be associated with the creep action produced by the couple of the dilatometry equipment over the sample. This event impedes the dilatometric curve to present the final stage of sintering where the shrinkage rate tends to values close to zero and, consequently, final densification is not reached. Additionally, the shrinkage curves of $\mathrm{Cu}-\mathrm{ZrO}_{2}$ composites are also plotted, demonstrating the clear influence of nanoparticles on the sintering progress. This can confirm that the addition of zirconia nanoparticles at small concentrations (up to $3 \mathrm{vol} \%$ ) is enough to promote a rising coverage on the copper particles surface, thus defining not only the rheological behavior but also the sintering process. Throughout heating in the sintering stage, the material transport is hampered due to a diffusion mass transport restriction promoted by ceramic phase. This effect is accentuated as the nanoparticles content increases and densification is barred. In fact, for samples with 1.0 and 3.0 vol\% $\mathrm{ZrO}_{2}$, sintering starts at 600 and 650 ${ }^{\circ} \mathrm{C}$, and the values of linear shrinkage at $900{ }^{\circ} \mathrm{C}$ reduces to approximately $5.0 \%$ and $3.5 \%$, respectively. Similar results were published by Vieira Jr. and co-authors regarding the colloidal processing of nickel matrix composites, indicating that densification was strongly affected by the presence of a small fraction of ceramic nanoparticles ${ }^{35,36}$.
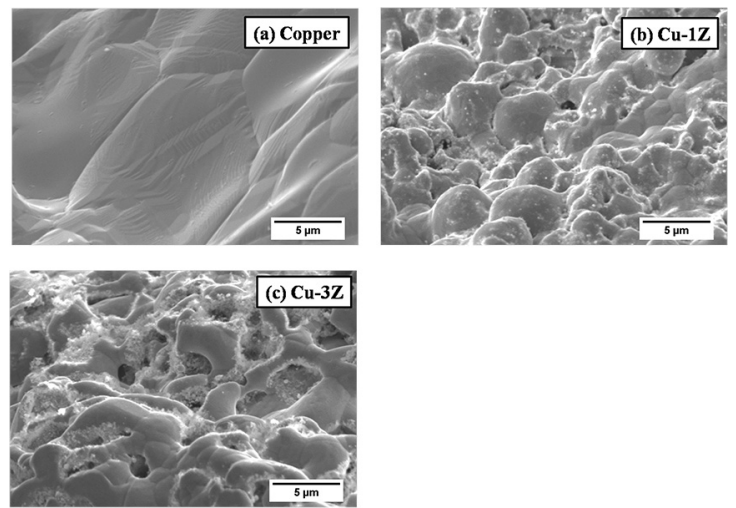

Figure 7. SEM images of transversal sections of the tapes sintered at $800{ }^{\circ} \mathrm{C}: \mathrm{Cu}, \mathrm{Cu}-1 \mathrm{Z}$, and $\mathrm{Cu}-3 \mathrm{Z}$.

Static sintering cycles were also performed with the purpose to evaluate the influence of temperature on the densification of the composites. The sintered density values obtained for copper and $\mathrm{Cu}-\mathrm{ZrO}_{2}$ tapes slightly decreased with increasing content of ceramic nanoparticles, as shown in Table 2. Three sintering temperatures were used to describe the thermal behavior of the composites, i.e. 800 , 900 , and $1000^{\circ} \mathrm{C}$. In the case of pure copper, a maximum density near to the theoretical (98.6\% TD) is reached at 900 ${ }^{\circ} \mathrm{C}$. The results confirm that the incorporation of zirconia reduces the sintering kinetics and temperatures of $1000{ }^{\circ} \mathrm{C}$ are necessary to achieve maximum densification. However, these temperatures $\left(900\right.$ and $1000{ }^{\circ} \mathrm{C}$ ) are very near to the melting point of copper, which takes place at about $1083^{\circ} \mathrm{C}$ and its vapor pressure changes drastically to $5.0 \cdot 10^{-5}$ Torr at $1000{ }^{\circ} \mathrm{C}^{2}$. Thus, a significative evaporation process is expected to occur, disallowing sintering in these temperatures.

Figure 7 shows SEM images of the transversal surfaces of the three tapes $(\mathrm{Cu}, \mathrm{Cu}-1 \mathrm{Z}$, and $\mathrm{Cu}-3 \mathrm{Z})$ sintered at 800 ${ }^{\circ} \mathrm{C}$. The copper tape has high densification and practically no residual pores and the surface appears significantly textured with stacked planes. The presence of zirconia nanoparticles on the surface of copper micrometric particles produces a remarkable increase of porosity in the microstructure of the samples $\mathrm{Cu}-1 \mathrm{Z}$ and $\mathrm{Cu}-3 \mathrm{Z}$. Moreover, in the case of $\mathrm{Cu}-3 \mathrm{Z}$ composite, aggregates of $\mathrm{ZrO}_{2}$ nanoparticles can be observed and the porosity becomes more interconnected.

Figure 8 shows the stress-strain curves obtained during the tensile strength tests of copper and $\mathrm{Cu}-\mathrm{ZrO}_{2}$ tapes sintered 
Table 2. Relative densities of green and sintered tapes of $\mathrm{Cu}, \mathrm{Cu}-1 \mathrm{Z}$ and $\mathrm{Cu}-3 \mathrm{Z}$.

\begin{tabular}{lcccc}
\hline \multirow{2}{*}{ Mixtures (vol\%) } & \multicolumn{4}{c}{ Relative densities (\% TD) } \\
\cline { 2 - 4 } & Green & $800{ }^{\circ} \mathrm{C}$ & $900{ }^{\circ} \mathrm{C}$ & $1000^{\circ} \mathrm{C}$ \\
\hline $\mathrm{Cu}$ & $54.5 \pm 0.2$ & $86.9 \pm 0.2$ & $98.6 \pm 0.3$ & $91.2 \pm 1.0$ \\
$\mathrm{Cu}-1 \mathrm{Z}$ & $54.2 \pm 0.2$ & $85.4 \pm 0.1$ & $93.2 \pm 1.0$ & $95.9 \pm 0.9$ \\
$\mathrm{Cu}-3 \mathrm{Z}$ & $52.2 \pm 0.9$ & $83.0 \pm 0.2$ & $82.4 \pm 0.2$ & $95.3 \pm 0.5$ \\
\hline
\end{tabular}

at $800{ }^{\circ} \mathrm{C}$. The pure copper tape exhibited a characteristic behavior of a polycrystalline single phase metal, which presented an elastic field, indicated by a yield stress. For the sintered pure copper, the yield stress is registered at a load of $85 \mathrm{MPa}$ and fracture occurs with an applied load of 125 $\mathrm{MPa}$. In the case of the $\mathrm{Cu}-1 \mathrm{Z}$ composite, the curve shows a considerable increase in the mechanical strength reaching a yield stress about $163 \mathrm{MPa}$, an increase over $90 \%$, with a rupture stress at $175 \mathrm{MPa}$. This increase can be explained by the presence of incoherent second phase particles that act like barriers to the motion of dislocations. Finally, for the composite with 3.0 vol\% zirconia nanoparticles the curve shows only an elastic field, characteristic of a brittle material. Moreover, in this case the fracture stress is only about $40 \mathrm{Mpa}$, confirming the lower densification of this material. These results demonstrate that the presence of zirconia nanoparticles attached at the copper surfaces in the composition $\mathrm{Cu}-1 \mathrm{Z}$ did not produce a complete covering of the copper particles, leading to a major influence on the mechanical behavior, and significantly enhances the fracture strength. For the $\mathrm{Cu}-3 \mathrm{Z}$ composites, there is an excess of nanozirconia particles remaining in the matrix and they retard densification, thus reducing the mechanical performance. This coating effect of zirconia nanoparticles on the copper particles surfaces is confirmed when compared surface tension values between $\mathrm{Cu}-\mathrm{ZrO}_{2}$ system. If the value of the surface tension of the minority phase $\left(\gamma_{\mathrm{ZrO} 2} \approx 1.14\right)^{37,38}$ is inferior than the major phase, copper $\left(\gamma_{\mathrm{Cu}} \approx 1.77\right)^{39}$, there is a tendency to attach and to produce a core-shell microstructure feature.

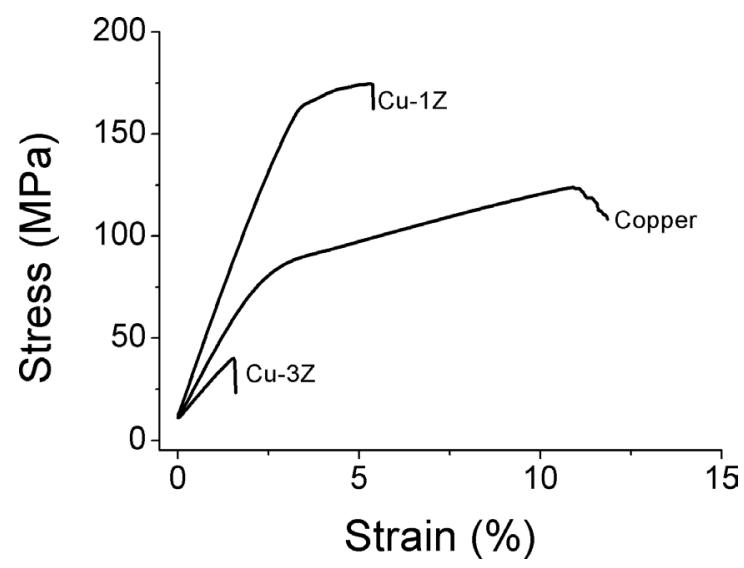

Figure 8. Stress versus strain curves for $\mathrm{Cu}$ and $\mathrm{Cu}-\mathrm{ZrO}_{2}$ composites sintered at $800{ }^{\circ} \mathrm{C} / 1 \mathrm{~h}$ in $\mathrm{Ar} / 5 \% \mathrm{H}_{2}$ atmosphere.
The fracture surfaces of the sintered specimens are shown in Figure 9. Copper alone shows a typical ductile topography fracture aspect with the presence of dimples. The addition of zirconia clearly changes the morphology and the fracture mechanisms. In the $\mathrm{Cu}-1 \mathrm{Z}$ material fracture becomes transgranular, due to the restriction to the plastic deformation imposed by zirconia nanoparticles. This is another evidence that the $\mathrm{ZrO}_{2}$ nanoparticles were incorporated into the copper matrix during sintering. The $\mathrm{Cu}-3 \mathrm{Z}$ tape shows intergranular fracture due to the low sinterability of the ceramic phase at that low sintering temperature, leading to poor mechanical strength. The aspect of surface fracture of $\mathrm{Cu}-3 \mathrm{Z}$ in Figure 9 supports the proposition that the copper particles are completely covered by $\mathrm{ZrO}_{2}$ nanoparticles. As it can be seen, copper particles maintain the spherical shape, demonstrating that the fracture occurs in the ceramic continuous phase.
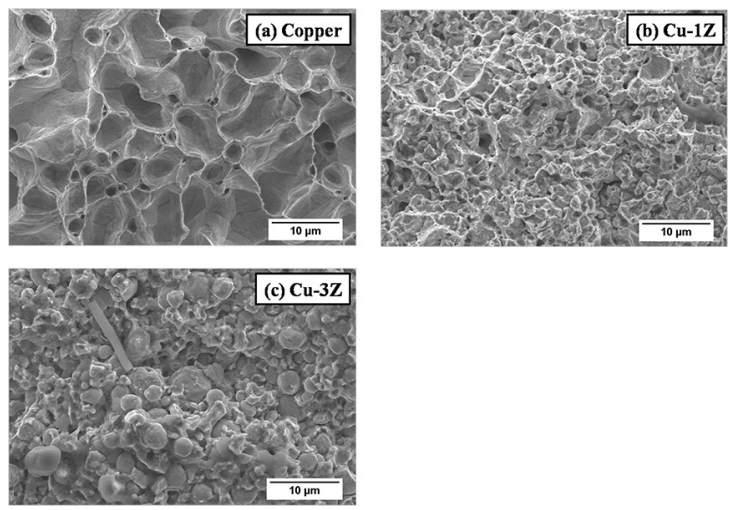

Figure 9. SEM images of the fracture surfaces of $\mathrm{Cu}, \mathrm{Cu}-1 \mathrm{Z}$ and $\mathrm{Cu}-3 \mathrm{Z}$ composites sintered at $800{ }^{\circ} \mathrm{C} / 1 \mathrm{~h}$ in $\mathrm{Ar} / \mathrm{H}_{2}$ atmosphere.

\section{Conclusions}

This work presented an alternative route to produce a ceramic nanoparticles reinforced metal composite via colloidal processing. A rheological study was performed to produce copper and $\mathrm{Cu}-\mathrm{ZrO}_{2}$ composite substrates by an aqueous tape casting process. The presence of the zirconia nanoparticles increased the viscosity of the copper suspensions due to the larger contribution to the total surface area. The addition of an polymeric emulsion to concentration of $3 \mathrm{vol} \%(\sim 1.5$ $\mathrm{vol} \%$ active matter) is enough to produce green tapes with required consistency and flexibility and a thickness ranging from 90 to $130 \mu \mathrm{m}$. Thermogravimetric and dilatometric 
tests were performed to optimize debinding and sintering, which were successfully achieved by heating at $350{ }^{\circ} \mathrm{C}$ in air for debinding and further sintering under $\mathrm{Ar} / 5 \% \mathrm{H}_{2}$ flowing atmosphere at $800{ }^{\circ} \mathrm{C}$ to perform the mechanical characterizations. When the sintering temperature was raised to $1000{ }^{\circ} \mathrm{C}$, the densification progress has been reduced due to evaporation phenomena. However higher sintering temperatures favored the densification of mixtures with zirconia. The incorporation of $1 \mathrm{vol} \%$ nanoparticles of zirconia is enough to form a nanostructured composite with a significant increase in tensile strength (about $92 \%$ ) over that of pure copper.

\section{Aknowledgements}

This work has been supported by CNPq (National Council for Scientific and Technological Development, Brazil), and CAPES (Coordination for the Improvement of Higher Education Personnel, Brazil) in the frame of the international cooperation program Science without Borders (Special Visiting Researcher grant, PVE A011/2013).

\section{References}

1. Upadhyaya GS. Sintered Metallic And Ceramic Materials: preparation, properties and applications. Hoboken: Wiley; 1999.

2. ASM International. ASM Handbook Volume 2: Properties and Selection. Nonferrous Alloys and Special Purpose Material. $10^{\text {th }}$ ed. Materials Park: ASM International; 1990.

3. Savitskii AP, Zhdanova VN, Gyrya ÉN. The effect of sintering temperature on the strength of powder copper subjected to repeated pressing. Soviet Powder Metallurgy and Metal Ceramics. 1964;3(4):311-315.

4. Kahler J, Heuck N, Wagner A, Stranz A, Peiner E, Waag A. Sintering of copper particles for die attach. IEEE Transactions on Components, Packaging and Manufacturing Technology. 2012;2(10):1587-1591.

5. Peng L. Fabrication and properties of $\mathrm{Ti}_{3} \mathrm{AlC}_{2}$ particulates reinforced copper composites. Scripta Materialia. 2007;56(9):729-732.

6. Goudah G, Ahmad F, Mamat O. Microstructural studies of sintered carbon nanotubes reinforced copper matrix composite. Journal of Engineering Science and Technology. 2010;5(3):272-283.

7. Kim C, Lim B, Kim B, Shim U, Oh S, Sung B, et al. Strengthening of copper matrix composites by nickel-coated single-walled carbon nanotube reinforcements. Synthetic Metals. 2009;159(56):424-429.

8. Tjong SC, Lau KC. Tribological behaviour of SiC particlereinforced copper matrix composites. Materials Letters. 2000;43(5-6):274-280.

9. Yih P, Chung DDL. Titanium diboride copper-matrix composites. Journal of Materials Science. 1997;32(7):1703-1709.

10. Zhang J, He L, Zhou Y. Highly conductive and strengthened copper matrix composite reinforced by $\mathrm{Zr}_{2} \mathrm{Al}_{3} \mathrm{C}_{4}$ particulates. Scripta Materialia. 2009;60(11):976-979.
11. Guillemet T, Geffroy PM, Heitz JM, Chandra N, Lu Y, Silvain JF. An innovative process to fabricate interphase-free copper/ diamond composite films for thermal management applications. Composites Part A: Applied Science and Manufacturing. 2012;43(10):1746-1753.

12. Uddin SM, Mahmud T, Wolf C, Glanz C, Kolaric I, Volkmer $\mathrm{C}$, et al. Effect of size and shape of metal particles to improve hardness and electrical properties of carbon nanotube reinforced copper and copper alloy composites. Composites Science and Technology. 2010;70(16):2253-2257.

13. Shehata F, Fathy A, Abdelhameed M, Moustafa SF. Preparation and properties of $\mathrm{Al}_{2} \mathrm{O}_{3}$ nanoparticle reinforced copper matrix composites by in situ processing. Materials \& Design. 2009;30(7):2756-2762.

14. Silvain JF, Le Petitcorps Y, Sellier E, Bonniau P, Helm V. Elastic moduli, thermal expansion and microstructure of copper-matrix composite reinforced by continuous graphite fibres. Composites. 1994;25(7):570-574.

15. Tu JP, Wang NY, Yang YZ, Qi WX, Liu F, Zhang XB, et al. Preparation and properties of $\mathrm{TiB}_{2}$ nanoparticle reinforced copper matrix composites by in situ processing. Materials Letters. 2002;52(6):448-452.

16. Wu JY, Zhou YC, Wang JY. Tribological behavior of $\mathrm{Ti}_{2} \mathrm{SnC}$ particulate reinforced copper matrix composites. Materials Science and Engineering: A. 2006;422(1-2):266- 271.

17. Sheibani S, Khakbiz M, Omidi M. In situ preparation of $\mathrm{Cu}-\mathrm{MnO}$ nanocomposite powder through mechanochemical synthesis. Journal of Alloys and Compounds. 2009;477(1-2):683-687.

18. Espinoza RG, Palma RH, Sepúlveda AO, Zúñiga A. Creep behavior of a dispersion-strengthened $\mathrm{Cu}$-Ti-Al alloy obtained by reaction milling. Materials Science and Engineering: $A$. 2008;498(1-2):397-403.

19. Zhang Z, Lee SI. Thin film solid oxide fuel cells with copper cermet anodes. Journal of Power Sources. 2010;195(11):34943497.

20. Sammes N, ed. Fuel Cell Technology. Reaching Towards Commercialization. London: Springer; 2006.

21. Kim CM, Kim J, Park K. Fabrication and structural properties of porous $\mathrm{Cu}-\mathrm{YSZ}$ cermets for solid. Powder Technology. 2014;425-431.

22. Twiname ER, Mistler RE. Tape Casting and Lamination. In: Buschow KHJ, Cahn RW, Flemings MC, Ilschner B, Kramer EJ, Mahajan S, et al., eds. Encyclopedia of Materials: Science and Technology. Oxford: Pergamon Press; 2001. p. 9083-9088.

23. Amorín H, Santacruz I, Holc J, Thi MP, Kosec JM, Moreno R, et al. Tape-Casting Performance of Ethanol Slurries for the Processing of Textured PMN-PT Ceramics from Nanocrystalline Powder. Journal of the American Ceramic Society. 2009;92(5):996-1001.

24. Snijkers F, de Wilde A, Mullens S, Luyten J. Aqueous tape casting of yttria stabilised zirconia using natural product binder. Journal of European Ceramic Society. 2004;24(6):1107-1110.

25. Sánchez-Herencia AJ. Water based colloidal processing of ceramic laminates. Key Engineering Materials. 2007;333:39-48. 
26. Mora M, Gimenoa F, Amaveda H, Angurel LA, Moreno R. Dispersant-free colloidal fabrication of $\mathrm{Bi}_{2} \mathrm{Sr}_{2} \mathrm{CaCu}_{2} \mathrm{O}_{8}$ superconducting thick films. Journal of European Ceramic Society. 2010;30(4):917-926.

27. Dias T, de Souza DPF. Placas cerâmicas obtidas por colagem de fita. Matéria (Rio J.). 2008;13(3):448-461.

28. Hotza D, Greil P. Review: aqueous tape casting of ceramic powders. Materials Science Engineering A: 2005;202(12):206-217.

29. Moreno R. The role of slip additives in tape casting technology: Part I: Solvents and dispersants. American Ceramic Society Bulletin.1992;71(10):1521-1531.

30. Vieira Jr LE, Rodrigues Neto JB, Kein AN, Hotza D, Moreno R. Colloidal processing of highly concentrated aqueous copper suspensions. Powder Technology. 2014;256:540 -544.

31. Moreno R. The role of slip additives in tape casting technology: Part II: Binders and plasticizers. American Ceramic Society Bulletin. 1992;71(11):1647-1657.

32. Santacruz I, Nieto MI, Moreno R. Rheological Characterization of Synergistic Mixtures of Carrageenan and Locust Bean Gum for Aqueous Gelcasting of Alumina. Journal of the American Ceramic Society. 2002;85(10):2432-2436.

33. Sánchez-Herencia AJ, Hernández N, Ferrari B, Moreno R. Complex structures by colloidal powder processing. In: Jurado
J, Egea JRJ. Processing and Microstructure-Property Relations in SOFC Components and Ceramic Gas-Separation Membranes. Madrid: CSIC; 2002, p. 1-129.

34. Brett J, Seigle L. Shrinkage of voids in copper. Acta Metallurgica Materialia. 1963;11(5):467-474.

35. Vieira Jr LE, Rodrigues Neto JB, Klein AN, Moreno R, Hotza D. Rheological and structural characterization of $\mathrm{Ni}-\mathrm{SiO}_{2}$ nanocomposites produced by aqueous colloidal processing. Journal of American Ceramic Society. 2011;94(12):4179-4183.

36. Vieira Jr LE, Rodrigues Neto JB, Klein AN, Hotza D, Moreno R. Effect of mechanical activation on microstructure and mechanical properties of aqueous colloidal processed nickel metal matrix nanocomposites. Material Science Forum. 2012;727-728:195-199.

37. Grau-Crespo R, de Leeuw NH, Hamad S, Waghmare UV. Phase separation and surface segregation in ceria-zirconia solid solutions. Proceedings of the Royal Society A. 2011;467(2131):1925-1938.

38. Aboushelib MN, Feilzer AJ, Kleverlaan CJ. Bonding to zirconia using a new surface treatment. Journal of Prosthodontics. 2010;19(5):340-346.

39. Padilha AF. Materiais de engenharia: Microestrutura e propriedades. $5^{\text {a }}$ ed. São Paulo: Hemus; 2000. 